\title{
FAKTOR-FAKTOR YANG MEMPENGARUHI PENENTUAN PEJABAT STRUKTURAL ESELON II DI PEMERINTAH DAERAH DAERAH ISTIMEWA YOGYAKARTA
}

\author{
Muhammad Eko Atmojo \\ Fakultas Ilmu Sosial dan Ilmu Politik Universitas Muhammadiyah Yogyakarta \\ Daerah Istimewa Yogyakarta, Indonesia \\ muhammadekoatmojo@yahoo.com
}

\begin{abstract}
ABSTRAK
Penentuan pejabat struktural setiap daerah mempunyai dinamika yang berbeda-beda, salah satunya adalah penentuan pejabat struktural di Daerah Istimewa Yogyakarta. Dimana Yogyakarta adalah satu-satunya provinsi yang mempunyai gubernur bukan berasal dari partai politik, hal inilah yang menjadikan dinamika penentuan pejabat struktural di Daerah Istimewa Yogyakrta dengan daerah lain berbeda. Dalam pelaksanaan penentuan pejabat struktural sangat rentan sekali terhadap factor -faktor politik ataupun factor patronage. Maka dari itu perlu pembenahan pada pelaksanaan proses rekruitmen pejabat struktural eselon II. Dengan adanya pembenahan system rekruitmen maka diharapkan pejabat struktural eselon II merupakan orang-orang pilihan yang mempunyai kompetensi dan integritas dalam menjalankan tugas. Dengan begitu maka akan tercipta pelayanan kepada masyarakat dengan baik karena penempatan pejabat struktural sesuai dengan kompetensi dan integritas masing-masing organisasi. Maka penggunaan metode merit system sangatlah tepat untuk proses rekuitmen pejabat struktural eselon II, sedangakan faktor yang bisa mempengaruhi penentuan pejabat struktural adalah faktor kompetensi, faktor prestasi kerja dan faktor penilaian secara objektif. Sedangkan untuk faktor kepentingan, faktor politik dan patronase tidak menjadi faktor penentu dalam pélaksanaan penentuan pejabat struktural di lingkungan Pemerintah Daerah Istimewa Yogyakarta. Dengan begitu menandakan bahwasannya pelaksnaan penentuan jabatan struktural di lingkungan pemerintah daerah istimewaa Yogyakarta sudah menggunakan merit system sehingga pejabat yang terpilih merupakan pejabat yang mempunyai kompetensi dan integritas untuk kepentingan public dan pelayanan publik.
\end{abstract}

Kata Kunci: Pejabat Struktural, Merit System, Kompetensi Pegawai, dan Rekruitmen.

\begin{abstract}
The determination of structural officials for each region has different dynamics, one of which is the determination of structural officials in the Special Region of Yogyakarta. Where Yogyakarta is the only province that has a governor who is not from a political party, this is what makes the dynamics of determining structural officials in the Special Region of Yogyakarta different from other regions. In the implementation of the determination of structural officials, they are very vulnerable to political or patronage factors. Therefore, it is necessary to improve the implementation of the recruitment process for echelon II structural officials. With the reform of the recruitment system, it is hoped that echelon II structural officers will be selected people who have the competence and integrity in carrying out their duties. That way, good service to the community will be created because the placement of structural officials is in accordance with the competence and integrity of each organization. So the use of the merit system method is very appropriate for the recruitment process of echelon II structural officials, while the factors that can influence the determination of structural officials are competency factors, work performance factors and objective assessment factors. As for the factors of interest, political and patronage factors were not the determining factors in the implementation of determining structural officials within the Government of the Special Region of Yogyakarta. This indicates that the implementation of structural position determination within the special regional government of Yogyakarta has used a merit system so that the elected officials are officials who have the competence and integrity for the benefit of the public and public services.
\end{abstract}

Keywords: Structural Officials, Merit System, Employee Competence, Recruitment. 


\section{Kebijakan: Jurnal Ilmu Administrasi \\ Volume 10, Nomor 1, Januari 2019 \\ E-ISSN: 2656-2820 \\ P-ISSN 1829-5762}

\section{PENDAHULUAN}

Undang-Undang Nomor 5 tahun 2014 tentang Aparatur Sipil Negara (ASN) merupakan salah satu bentuk reformasi birokrasi di bidang kepegawaian. Dengan adanya undang-undang ini ada beberapa hal yang diperbaiki dalam system kepegawaian, terutama dalam penentuan pejabat struktural. Dengan berlakunya UU ASN dalam penentuan pejabat struktural tidak lagi menggunakan system promosi jabatan akan tetapi menggunakan system lelang jabatan sehingga pejabat yang terpilih merupakan pejabat yang mempunyai kompetensi dan bisa bekerja secara professional. Tujuan diadakannya perubahan system dalam penentuan pejabat struktural adalah untuk menumbuhkan kompetisi yang fair dan sehat, objektif serta mendapatkan sumber daya aparatur yang kompeten dan professional.

Hal ini merupakan salah satu bentuk reformasi birokrasi di bidang kepegawaian. Zulchaidir (2011) menyatakan bahwa salah satu upaya yang telah dilakukan oleh pemerintah dalam peningkatan kapasitas sumber daya aparatur adalah melakukan "reformasi birokrasi" pada bidang kepegawaian yang diyakini akan membawa pada suatu kondisi birokrasi pemerintahan sebagai pelayanan publik yang diharapkan oleh masyarakat. Reformasi birokrasi dibidang kepegawaian memang sangat penting, adanya hubungan secara langsung antara masyarakat dengan aparatur sipil Negara. Dengan adanya reformasi birokrasi ini diharapkan dapat menciptakan kinerja birokrasi yang kompeten dan professional.

Oleh karena itu penentuan pejabat struktural merupakan hal yang sangat penting dalam pelaksanaan reformasi birokrasi. Mengingat pejabat struktural merupakan jabatan yang sangat strategis dalam Organisasi Perangkat Daerah (OPD), selain itu jabatan tersebut merupakan jabatan yang mempunyai kewenangan dalam pengambilan keputusan dan kebijakan. Sehingga dalam penentuan pejabat struktural mempunyai dinamika yang sangat menarik sekali untuk dibahas dan diteliti. Hal ini tidak lepas dari dinamika yang ada di setiap daerah, dimana dinamika dalam penentuan pejabat struktural disetiap daerah mempunyai perbedaan yang mendasar. Wahiyuddin (2012) menyatakan rekrutmen, pengangkatan dan pemindahan, serta pembinaan karier pegawai negeri sipil sangat tidak memperhatikan prinsip kompetensi akan tetapi didasarkan pada pertimbangan politik.

Permasalahan pengangkatan pejabat struktural merupakan salah satu masalah yang mendapatkan banyak sorotan dari beberapa kalangan, mengingat banyak sekali kepentingankepentingan dalam proses pengangkatan tersebut. Hal ini terjadi karena selama ini proses pengangkatan atau rekruitmen pejabat struktural cenderung menggunakan system yang tertutup (closes career system). Sehingga dengan pola tersebut maka sangat rawan sekali akan adanya intervensi dalam penentuan pejabat struktural. Proses seperti ini sangat kental dengan praktek-praktek korupsi, kolusi dan nepotisme dan tidak didasari dengan merit system atau kompetensi. Selain itu ada beberapa permasalahan lain dalam proses rekruitmen pejabat struktural dengan menggunakan metode tertutup diantaranya adalah sebagai berikut: Pertama, Lewis dkk dalam Sudrajat (2014) berpendapat pengisian jabatan struktural cenderung berorientasi pada pembinaan karier pegawai negeri secara berjenjang, yang lebih mengedepankan senioritas dalam kepangkatan dan tidak mengedepankan aspek prestasi kerja dan kompetensi, sehingga hal ini dapat menimbulkan implikasi yang negatif pada pejabat struktural yang berupa lemahnya kompetensi, kurangnya motivasi dan birokrasi yang tidak efisen. Kedua, menurut Sudrajat (2014) sistem penilaian dalam jabatan struktural belum sepenuhnya berbasis pada merit sistem, sehingga penilaian yang diberikan kepada Baperjakat sering sekali tidak didasarkan pada alat ukur yang distandarisasi sehingga penilaianya menjadi subyektif dan sarat intervensi. Ketiga, menurut Sudrajat (2014) pejabat yang diberi kewenangan untuk menetapkan pejabat struktural merupakan jabatan politis, seperti Gubernur, Bupati, dan Wali Kota, di mana pejabat-pejabat tersebut adalah pembina kepegawaian di daerah. Dari kewenangan yang diberikan kepada pembina kepegawaian, maka sering sekali menimbulkan masalah netralitas dalam 
pengangkatan pejabat struktural yang dipilih. Prasojo menjelaskan bahwa rekrutmen pegawai melalui lelang jabatan menjadi pengungkit terbesar perubahan birokrasi, selain menumbuhkan kompetisi yang sehat, fair, obyektif, juga bebas dari KKN. Dengan adanya promosi terbuka ini menguntungkan kepala daerah, menteri, dan kepala LPNK, sebab dengan cara ini akan mampu mendapatkan caloncalon pimpinan satuan kerja perangkat daerah (SKPD), serta pejabat terbaik (JPNN, 2013).

Lelang jabatan merupakan salah satu bentuk merit system yang diterapkan oleh pemerintah guna mewujudkan birokrasi yang professional serta pegawai yang mempunyai kompetensi. Defriadi (2016) menyatakan bahwa proses pelaksanaan lelang jabatan masih banyak sekali permasalahan dan patologi-patologi birokrasi dalam penerapannya sehingga reformasi birokrasi yang seharusnya memperbaiki system pelayanan public berdasarkan prinsip melayani menjadi terstigma negatif. Kemudian lelang jabatan yang akan di selenggarakan tidak memungkiri akan membuka jalan nepotisme bagi kelompok-kelompok kepentingan yang ingin menempati posisi jabatan struktural karena melihat sejarah Pemerintah DIY itu sendiri masih belum cukup pengalaman dalam hal lelang terbuka untuk penempatan formasi jabatan, walaupun bisa dikatakan pemerintah DIY sudah lama menggunakan sistem lelang jabatan namun lelang jabatan yang diterapkan hanya sebatas lelang jabatan secara mufakat hal ini diungkapkan oleh Agus Supriyanto selaku Kepala Badan Kepegawaian Daerah (Harian Jogja, 2015). Berdasarkan fenomena yang telah disebutkan maka penulis ingin focus pada factor-faktor yang mempengaruhi penentuan pejabat struktural eselon II di Pemerintah Daerah Daerah Istimewa Yogyakarta.

\section{METODE}

Penelitian ini menggunakan metode kualitatif. Metode penelitian kualitatif biasanya disebut juga dengan metode penelitian naturalistic, karena penelitiannya dilakukan pada kondisi $\mathbf{i}$ yang alamiah (natural setting), disebut juga dengan metode kualitatif karena data yang terkumpul dan analisisnya lebih bersifat kualitatif (Sugiyono, 2014). Metode kualitatif merupakan prosedur pengumpulan data yang menghasilkan data deskriptif berupa kata-kata tertulis atau lisan dari orang-orang dan perilaku yang diamati. Penelitian ini akan dilaksanakan di Badan Kepegawaian Daerah (BKD) dan Badan Pertimbangan Jabatan dan Kepangkatan (BAPERJAKAT) Daerah Istimewa Yogyakarta. Teknik pengumpulan data pada penelitian ini menggunakan observasi non-partisipasion, wawancara, dan dokumentasi. Sedangkan analis data menggunakan metode Miles dan Huberman (2007) terjemahan Tjepjep Rohendi Rohidi dalam Nurliana (2013) mengatakan ada 3 macam analis data model interaktif yang dapat digunakan, yaitu; (a) reduksi data; (b) penyajian data; (c) menarik kesimpulan/verivikasi.

\section{PEMBAHASAN}

Promosi jabatan struktural eselon II sangat rentan dipengaruhi oleh factor politik, serta factor kepentingan lainnya. Hal ini banyak terjadi karena sebagaian besar pejabat pembina kepegawaian sebagai pejabat politik. Jabatan struktural eselon II rentan dipengaruhi karena jabatan tersebut merupakan jabatan strategis dalam struktur organisasi birokrasi pemerintah daerah, selain itu jabatan struktural eselon II juga merupakan jabatan yang berperan penting dalam pengembilan kebijakan maupun pembuat kebij akan. Oleh karena itu, posisi jabatan struktural harus diisi dengan kualifikasi yang jelas serta mempunyai kompetensi sesuai dengan bidangnya, jika tidak maka akan sangat mudah sekali untuk diintervensi sehingga kebijakan-kebijakan yang diambil bisa menguntungkan kelompok tertentu atau segelintir orang.

Pejabat Pembina Kepegawaian merupakan jabatan politik yang mempunyai bargaining position untuk memepengaruhi keputusan pejabat publik. Dengan adanya bargaining position tersebut maka kebijakan-kebijakan yang dikeluarkan oleh pejabat publik bisa menguntungkan kelompok tertentu atau oknum-oknum tertentu. Hal semacam ini banyak sekali terjadi di Indonesia, terutama di daerah- 


\section{Kebijakan: Jurnal Ilmu Administrasi \\ Volume 10, Nomor 1, Januari 2019 \\ E-ISSN: 2656-2820 \\ P-ISSN 1829-5762}

daerah yang melakukan pemilihan kepala daerah, dimana pelaksanaan promosi jabatan tidak didasari dengan kompetensi melainkan factor keluarga, kerabat, pendukung dalam pencalonan dan lain sebagainya. Hal ini berbeda dengan Daerah Istimewa Yogyakarta yang notabennya tidak melakukan pemilihan gubuernur. Gubernur di Daerah Istimewa Yogyakarta dipilih melalui penetapan sehingga pejabat pembina kepegawaian di Daerah Istimewaa Yogyakarta bukan pejabat politik. Akan tetapi tidak adanya pemilihan kepala daerah bukan berarti tidak ada pengaruh politik sama sekali, melainkan peluang pengaruh politik sangat kecil dibandingkan dengan daerah yang melakukan pemilihan kepala daerah. Selain itu pejabat pembina kepegawaian Daerah Istimewa Yogyakarta mempunyai komitmen yang kuat dalam membangun sumber daya aparatur, hal ini dapat dilihat dengan adanya metode assessment center yang diterapkan untuk penentuan pejabat struktural eselon II. Dengan adanya metode dan komitmen tersebut maka diharapkan pejabat struktural yang di rekrut merupakan pejabat yang mempunyai kompetensi sehingga bisa bekerja dengan efektif, efesien serta bisa mewujudkan profisionalisme.

Sebelum adanya undang-undang Aparatur Sipil Negara penentuan jabatan struktural atau promosi jabatan sangat indentik dengan kepentingan maupun praktek patronase. Hal ini terjadi karena pejabat pembina kepegawaian merupakan jabatan politik dan mempunyai keleluasaan dalam pengangkatan, pembinaan karir dan pemindahan pegawai. Sehingga banyak sekali terjadi penempatan pejabat struktural bukan berdasarkan kompetensi melainkan berdasarkan faktor kepentingan, faktor politik maupun faktor kedekatan. Hal ini senada denan pernyataan Wahiyuddin (2012) yang menyatakan bahwa rekrutmen, pengangkatan dan pemindahan, serta pembinaan karier pegawai negeri sipil sangat tidak memperhatikan prinsip kompetensi akan tetapi didasarkan pada pertimbangan politik.

Di era undang-undang kepegawaian yang lama memang penentuan pejabat structural tidak belum sepenuhnya berbasis merit system, dan kebanyakan penentuan pejabat struktural lebih tertutup sehingga masyarakat tidak bisa mengontrol secara langsung. Dengan metode yang tertutup tersebut maka akan muncul kepentingan-kepentingan atau faktor-faktor lain yang dapat mempengaruhi penentuan pejabat struktural. Maka dari itu perlu adanya metode baru untuk menentukan pejabat struktural, supaya pejabat struktural yang menduduki jabatan tesebut merupakan pejabat yang mempunyai kompetensi dan professional. Yogyakarta adalah salah satu daerah yang menerapkan penentuan pejabat struktural harus menggunakan assessment center dan fit and proper test, sehingga pejabat yang akan terpilih benar-benar pejabat yang mempunyai kompetensi dan sesuai dengan kebutuhan.

Jabatan struktural memang jabatan yang sangat strategis, dengan begitu potensi praktek patronase unsur kepentingan politik maupun kepentingan lainnya sangat terbuka lebar di setiap daerah baik provinsi maupun kabupaten/kota. Mengingat jabatan struktural merupakan jabatan yang sangat penting dalam sebuah birokrasi, dimana keputusan dan pengambilan kebijakan di tangan pejabat struktural (Sedarmayanti dalam Azhzhahiri, 2012). Maka dari itu perlu adanya komitmen kepala daerah untuk membangun dan mengembangkan sumber daya aparatur yang profesional, selain itu dalam pemilihan pejabat struktural juga harus didasari dengan faktor kompetensi bukan faktor yang lain. Hal ini seharusnya diterapkan disetiap daerah baik yang melakukan pemilukada maupun yang tidak melakukan pemilukada seperti Daerah Istimewa Yogyakarta. Sebagai daerah yang tidak melakukan pemilihan kepala daerah bukan berarti bebas dari faktor politik maupun patronase dan nepotisme, akan tetapi unsur tersebut mempunyai peluang lebih kecil dibandingkan dengan daerah lain yang melakukan pemilihan kepala daerah. Hal ini dapat terjadi karena pejabat Pembina kepegawaian di Pemerintah Daerah Istimewa Yogyakarta bukan berasal dari kalangan politik atau partai politik, sehingga unsur kepentingan politik sangat kecil sekali terjadi. Sedangakan jika kita melihat daerah lain yang melakukan pemilihan kepala daerah dimana pejabat Pembina 


\section{Kebijakan: Jurnal Ilmu Administrasi \\ Volume 10, Nomor 1, Januari 2019 \\ E-ISSN: 2656-2820 \\ P-ISSN 1829-5762}

kepegawaiannya berasal dari pejabat politik atau kalangan politik, sehingga praktek patronase maupun faktor kepentingan mempunyai peluang yang sangat lebar sekali. Hal ini bisa terjadi karena pejabat Pembina kepegawaian di daerah yang melakukan pemilu kepala daerah berasal dari kalangan politik, sehingga bergening position partai politik sangat kuat dan dapat mempengaruhi pejabat publik. Hal ini sangat berbeda dengan pelaksanaan promosi atau penentuan pejabat struktural di Pemerintah Daerah Istimewa Yogyakarta, dimana kompetensi dan profesionalisme masih menjadi prioritas utama sehingga pejabat yang menduduki jabatan struktural merupakan pejabat yang profesional dan sesuai dengan kebutuhan. Sehingga kebijakan yang diambil lebih mengutamakan kepentingan public dibandingkan dengan kepentingan politik.

Untuk menentukan bagaiamana sikap profesionalisme bagi pejabat struktural dapat dilihat melalui dua hal: pertama melalui assessment center, dimana tujuan diadakannya assessment adalah untuk mengukur sejauhmana kompetensi yang dimiliki oleh pegawai dalam melaksanakan tugas sesuai bidangnya. Dalam metode assessment ini ada beberapa test yang harus dilakukan oleh calon pejabat struktural diantaranya adalah forum grup discussion, psikotes, dan kuesioner kompetensi. Sedangkan untuk yang kedua adalah dengan cara wawancara dan uji gagasan atau fit and proper test, dalam pelaksanaan uji gagasan tersebut calon pejabat dinilai tentang kemampuannya dalam menyampaikan gagasan terkait jabatan yang akan diduduki atau dipilih. Selain itu pejabat struktural juga dituntut untuk mempunyai pengetahuan yang luas tentang isu-isu strategis, regulasi-regulasipa saja yang terkait dengan bidang jabatan tersebut. Sehingga dengan adanya assessment dan fit and proper test tersebut maka akan membentuk karakter profesionalisme seorang pejabat struktural.

Selain kompetensi yang dibutuhkan dalam penentuan pejabat struktural di Pemerintah Daerah Istimewa Yogyakarta adalah prestasi kerja, dimana prestasi kerja merupakan komponenen terpenting dalam penilaian layak tidaknya seseorang untuk menjadi pejabat strtuktural. Unsur prestasi kerja ini dapat dilihat dari masa kerja pegawai, daftar riwayat hidup pegawai, pengalaman pegawai, serta riwayat jabatan pegawai selama menjadi aparatur sipil Negara. Mengenai prestasi pegawai ini bukan berarti hanya prestasi dalam skala regional saja melainkan skala nasional dan internasional juga menjadi faktor penilaian dalam penentuan pejabat struktural eselon II di Pemerintah Daerah Istimewa Yogyakarta. Prestasi kerja pegawai dapat dilihat dari dua hal yaitu dilihat dari kinerja pegawai dan kedisiplinan pegawai. Dengan adanya prestasi kerja maka akan mendukung kompetensi pegawai yang dimiliki terutama bagi pegawai yang akan menduduki jabatan struktural.

Selanjutnya adalah penilaian yang dilakukan secara objektif, dimana tujuan dari penilaian ini adalah untuk melihat seberapa besar kemampuannya atau mengenai kepribadiannya. Jika kita mengacu pada undang-undang aparatur sipil Negara mengenai lelang jabatan atau seleksi terbuka dijelaskan bahwa harus ada penilaian berdasarkan objektifitas, sehingga akan mengurangi atau meminimalisir tingkat subjektifitas yang dirasa akan merugikan atau proses lelang jabatan yang mempunyai semangat kompetitif dan terbuka. Dengan semangat kompetitif dan terbuka maka pegawai akan bersaing secara sehat, dan tidak ada unsur politik, faktor kedekatan maupun patronase dan nepotisme. Jika dilihat sebelum adanya undang-undang aparatur sipil Negara penentuan pejabat struktural masih sangat rawan sekali akan faktor politik, faktor kedekatan maupun patronase dan nepotisme. Hal ini dapat dibuktikan dengan banyaknya pejabat struktural yang diganti ketika pelaksanaan pemilu kepala daerah usai dan telah dilantiknya kepala daerah baru.

Jika melihat proses penentuan yang dilaksanakan di lingkungan Pemda Daerah Istimewa Yogyakarta maka sistem yang digunakan dalam penentuan jabatan struktural adalah merit sistem. Hal ini terlihat dimana dalam penempatan pejabat struktural eselon II kompetensi dan profesionalisme menjadi faktor utama serta didukung dengan prestasi kerja dan penilaian secara objektif. Sehingga pejabat yang menduduki jabatan strategis benar-benar pegawai yang mempunyai kompetensi dan profesional dalam bekerja. Wajar jika ada pegawai yang mempunyai pangkat dan golongan tinggi 
akan tetapi jabatannya hanya sebagai kepala seksi ataupun staf, tetapi ada pegawai baru yang memenuhi syarat maka dia bisa menduduki jabatan yang tinggi dan strategis bila mempunyai komptensi tinggi. Dengan adanya system ini maka kompetisi antara pegawai/Promosi jabatan atau penempatan pegawai berdasarkan sistem merit ini akan memperkuat manajemen karir pegawai, sehingga semua pegawai mempunyai peluang yang sama untuk dipromosikan dan meningkatkan karir berdasarkan kompetensi yang dimilikinya. Dengan adanya merit sistem maka penempatan pegawai menggunakan prinsip the right man on the right place. Dimana penempatan pegawai berdasarkan kompetensi dan kebutuhan organisasi bukan berdasarkan faktor politik, faktor kedekatan maupun patronase dan nepotisme. Penempatan pegawai berdasarkan merit system di lingkungan Pemerintah Daerah Istimewa Yogyakarta sebenarnya sudah dilakukan sejak sebelum adanya undang-undang aparatur sipil Negara. Hal ini dapat dilihat dengan adanya beberapa kriteria maupun tahapan seleksi yang harus dipenuhi dan dilalui oleh calon pegawai yang akan dipromosikan kejabatan srtuktural eselon II. Adapun tahapan test yang harus dilalui oleh calon pejabat struktural adalah seleksi adminsitrasi, asesment center, fit and proper test, fakta integritas dan evaluasi setiap 6 bulan sekali (Atmojo, 2016). Hal inilah yang membedakan antara Pemerintah Daerah Istimewa Yogyakarta dengan daerah lain, karena daerah lain belum banyak yang menggunakan metode tersebut dalam penempatan pejabat struktural eselon II.

\section{KESIMPULAN}

Pada pelaksanaan penentuan pejabat struktural di lingkungan Pemerintah Daerah Istimewaa Yogyakarta ada beberapa faktor yang harus diperhatikan. Adapun faktor tersebut adalah faktor kompetensi menjadi faktor yang paling utama, faktor prestasi kerja dan faktor penilaian secara objektif. Faktor kompetensi merupakan faktor utama yang harus diperhatikan, karena dengan adanya kompetensi maka pejabat yang akan di promosikan atau ditempatkan dalam jabatan struktural merupakan pejabat yang sesuai dengan kebutuhan, sehingga kebijakan yang diambil adalah kebijakan yang memihak public. Faktor prestasi kerja merupakan faktor pendukung dalam penentuan jabatan struktural, mengingat prestasi kejra juga merupakan hal penting dalam penilaian. Untuk prestasi kerja bisa dilihat dari rekam jejak selama menjadi aparatur sipil Negara maupun prestasi selama memimpin. Faktor penilaian, dalam penentuan pelaksanaan jabatan struktural penilaian menjadi hal yang sangat pokok mengingat dengan adanya undang-undang baru penilaian objektif harus dilakukan secara terbuka, hal ini dilakukan untuk menjaga nilai kompetititf dan keterbukaan. Dengan adanya penilaian objektif maka antar pegawai bisa bersaing secara sehata dalam memperebutkan jabatan struktural, bukan karena ada unsur politik maupun unsur yang lain melainkan berdasarkan merit system.

Undang-undang aparatur sipil Negara yang baru memang pemerintah daerah harus melakukan lelang jabatan, atau penempatan pejabat struktural harus berdasarkan merit system. Selain dengan adanya semangat baru dan undang-undang baru sebenarnya Pemerintah Daerah Istimewa Yogyakarta sudah melaksanakan merit system dengan undang-undang kepegawaian yang lama yaitu dengan beberapa metode yang diwajibkan bagi calon pegawai atau pejabat yang akan dipromosikan ke jabatan struktural eselon II. Adapun metode yang dilakukan adalah dengan menggunakan assessment center dan fint and proper test, selain itu ada juga psikotest dan pernjanjian fakta integritas. Maksud dan tujuan dari adanya beberapa tahapan test tersebut adalah untuk menciptakan pejabat yang mempunyai kompetensi dan profesional sehingga kebijakan-kebijakan yang diambil meruakan kebijakna yang memihak kepada public bukan berpihak kesegelintir orang atau kelompok tertentu. Selain itu hal ini juga bagian dari komitmen pejabat Pembina kepegawaian yang ingin menciptakan sumber daya aparatur yang kompeten, professional dalam pemberian pelayanan public kepada masyarakat. 


\section{Kebijakan: Jurnal Ilmu Administrasi \\ Volume 10, Nomor 1, Januari 2019 \\ E-ISSN: 2656-2820 \\ P-ISSN 1829-5762}

DAFTAR PUSTAKA

Atmojo, Muhammad Eko. (2016). Analisis Proses Promosi Jabatan Aparatur Sipil Negara Studi Kasus: Proses Promosi Jabatan Stuktural Eselon II di Pemerintah Daerah Daerah Istimewa Yogyakarta Tahun 2014. Aristo Jurnal, Vol 7, Juli.

Azhzhahiri, Bhasir (2012). Recruitment Analysis Through Open Bidding Announcement in the Selection of Prospective Echelon II. International Journal of Administrative Science \& Organization, Bisnis \& Birokrasi, Volume 19, Number 3.

Defriadi, Elvin. (2016). Rekrutmen Pejabat Struktural Melalui Model Lelang Jabatan Di Pemerintah Provinsi Daerah Istimewa Yogyakarta. Skripsi. Universitas Muhammadiyah Yogyakarta.

Nurliana (2013). Pengelolaan Alokasi Dana Desa (ADD) Dalam Pembangunan Fisik di Desa Sukomulyo Kecamatan Sepaku Kabupaten Penajam Paser Utara. Journal Administrasi Negara, Volume 1. No 3.

Sudrajat, Tedi (2014). Eksistensi Kebijakan Pengisian Jabatan Struktural Dalam Kerangka Pengembangan Sumber Daya Manusia Aparatur Berbasis Merit. Jurnal Kebijakan dan Manajemen PNS, Volume 8 Nomor 1 Juni.

Sugiyono, 2014. Metode Penelitian Kuantitatif, Kualitatif dan R\&D. Alfabeta, Bandung. Wahiyuddin, Laode (2012). Politisasi Pejabat Struktural (Study Kasus Politisasi Pejabat

Struktural Eselon II di Sekretariat Daerah Kabupaten Muna Sulawesi Tenggara).

Tesis, Universitas Gajah Mada.

Zulchaidir (2011). Proses Rekrutmen Pimpinan Birokrasi Pemerintah Daerah di Kabupaten Sleman dan Kota Parepare. Jurnal Studi Pemerintahan, Volume 2 Nomor 2 Agustus.

JPNN. 2013. Lelang Jabatan Untungkan PNS dan Kepala Daerah. Diakses pada tanggal 4 Oktober 2016 pada pukul 21.43 dari (m.jpnn.com/news.php?id=166257).

Sabandar Switzy. 2015. Pemda DIY Pesimistis Dengan Sistem Merit. Diakses pada tanggal 15 Oktober 2016 pada pukul 13.00 dari (http://www.harianjogja.com/baca /2015/06/08/pemda-diypesimistis-dengan-sistem-merit-611986). 